\title{
THE EFFECT OF FINANCIAL LITERATURE, MOTIVATION, AND RISK ON INVESTMENT IN INDONESIA THROUGH THE IMPACT OF COVID-19 AS INTERVENING VARIABLES
}

\author{
Jufriadi \\ UIN Alauddin Makassar \\ Email: adijufri84@yahoo.co.id
}

\begin{abstract}
This study aims to determine the effect of financial literacy, motivation, and risk on investment in Indonesia through the impact of covid-19 as an intervening variable. This research is a descriptive study that tries to explain the effect of each variable based on references and previous research results. In general, based on the theory and the results of previous research, it shows that financial literacy and motivation greatly affect the desire to invest in Indonesia as well as the risk that does not affect investment because it is a factor that must be anticipated by economic actors. However, the impact of COVID-19 has caused investment in Indonesia to be greatly affected.
\end{abstract}

Keywords: Impact of Covid-19, Indonesia, Investment, Financial Literacy, Motivation, and Risk

\section{INTRODUCTION}

Technological development is something that can be utilized by every individual in all lines of life, including entrepreneurs. Entrepreneurs must be able to take advantage of technological developments in all aspects of their decisionmaking. In everyday life, IT plays an important role regardless 
of age, IT is something that must and is a basic need for all individuals. ${ }^{1}$, This shows that technological developments will help entrepreneurs and economic actors in gaining an understanding of finance. Understanding can be obtained in making decisions. The understanding will finance will assist economic actors in determining attitudes toward investing activities. The results of research conducted $\mathrm{by}^{2}$. with the title, The Effect of Human Resources Financial Literacy and Risk Attitude on Investor Motivation concluded that financial literacy is needed as an ability for investors who want to make financial decisions (investment). This is slightly different from the results of research conducted ${ }^{3}$ entitled the effect of financial literacy and financial attitudes on people's financial management behavior with intention as an intervening variable which concludes that financial literacy has a positive but not significant effect on intention or desire to invest.

In addition to financial understanding, motivation also has an important role in making investments. Motivation can be defined as encouragement or enthusiasm for individuals to take actions or activities and behave. Motivation

\footnotetext{
1Sugiantini. BERBAGAI MANFAAT TEKNOLOGI BAGI KEHIDUPAN MANUSLA. Taken back from https://sugiantini.blog.institutpendidikan.ac.id: Berbagai Manfaat Teknologi Bagi Kehidupan Manusia are accessed (2021, June 15 June)

${ }^{2}$ Abadi, HE, \& all, a. The effect of human s esources financial literacy and risk attitude on investors. International Journal of Human Capital in Urban Management, doi:: 0.22034/IJHCUM.2021.02.08 ( February 8, 2021 edition ). h. 191

${ }^{3}$ R. Anugerah, Pengaruh Literasi Keuangan dan Sikap Keuangan. http:// repositori.uin-alauddin.ac.id/, 92. In the access date of 15 April 2021.
} 


\section{Jufriadi}

plays an important role in growing one's interest in investing because motivation is the spirit that drives someone to do something $^{4}$ With this motivation, a person will have a lighter/trigger to move and carry out activities. Similar research was conducted by Pajar \& Putikaningsih (2017) and Nisa \& Zulaika $(2017)^{5}$, stated that investment motivation affects students' interest in investing in the capital market. More from Sulistyowati's research $(2015)^{6}$ states that extrinsic motivation has a significant effect on investment interest. Saputra stated that motivation had a significant positive effect on investment interest. Of course, many things affect the motivation of economic actors in investing.

The role of motivation is so great for an economic actor in determining the direction of his decision-making policies. Many factors encourage a person/economic actor to invest. Among them are the desire to make a profit, take advantage of idle cash, speculate to increase market

4 A. Darmawan, Pengetahuan Investasi, Motivasi Investasi, Literasi Keuangan dan Lingkungan Keluarga Pengaruhnya Terhadap Investasi di Pasar Modal. https://www.researchgate.net/journal/Jurnal-IlmiahAkuntansi-dan-Keuangan-2548-9453. Accessed on May 25, 2021

5 A. Darmawan, Pengetahuan Investasi, Motivasi Investasi, Literasi Keuangan dan Lingkungan Keluarga Pengaruhnya Terhadap Investasi di Pasar Modal. https://www.researchgate.net/journal/Jurnal-IlmiahAkuntansi-dan-Keuangan-2548-9453. Accessed on May 25, 2021

6 A. Darmawan, Pengetahuan Investasi, Motivasi Investasi, Literasi Keuangan dan Lingkungan Keluarga Pengaruhnya Terhadap Investasi di Pasar Modal. https://wmw.researchgate.net/journal/Jurnal-IlmiahAkuntansi-dan-Keuangan-2548-9453. Accessed on May 25, 2021 
sentiment, and the desire to control/become the majority owner of a company.

Investments made by economic actors consist of short-term investments and long-term investments. Shortterm investments are investments made in a short time, while long-term investments are investments aimed at old age so that investors have a long time to enjoy the results of their investments.

Investing is one way to diversify sources of income so that the income stream increases. This is because economic actors do not only rely on funds that settle in savings but how to rotate these funds so that they can produce even more. However, before investing, economic actors must first understand/have financial literacy related to the investment itself. In the credit.com simulation, it is stated that in simple terms investment is a purchase or expenditure that is not intended for consumption or daily needs but as a form of production. This form of production means that the expenditure made aims to process and develop something to make a profit. Investments can be made by investing in business capital or investing in banking investment products such as stocks and mutual funds?

In investing, of course, economic actors hope to make a profit. However, investment as a business activity cannot be

${ }^{7}$ Kredit.com,S. bttps://wnw.simulasikredit.com/. Taken back from https://www.simulasikredit.com/: https://www.simulasikredit.com/ accessed on June 12,2021 


\section{Jufriadi}

separated from the risks in doing business. The investment world is a world full of risk, risk, and risk. It even seems that hearing or reading the word investment is the same as hearing or reading the word "risk". The two cannot be separated. However, when someone does not dare to take risks, economic actors will also lose the opportunity to make profits. According to Abdullah Umar in his writing entitled Dare to Take Risks, he argues that Dare take risks is one of the keys in starting a business, because in this component many items follow, namely Dare to lose, Dare to take decisions, Dare to face problems, Dare to refrain from using company money for fun, and dare to go bankrupt. That's just a little risk that exists when setting up a business. Therefore, economic actors should have the courage and strategy in managing risk.

The risk of experiencing losses in investing in stocks is an integral part of investing in stocks. Most investors, both fledgling and experienced, usually already aware will any such risks, however rare among those who want to pay special attention to it. Whenever the author meets with fellow investors, usually they just like to talk about how much potential profit can be achieved, without wanting to mention the slightest risk of loss that could be suffered. In essence, when investors began to invest in stocks, then what comes to mind is again of something, but did not imagine at all about how large the losses that may be suffered, or rather do not want to think about it. ${ }^{8}$

8 Hidayat, T. bttps://wmw.tegubbidayat.com/. Taken back from https://www.teguhhidayat.com/ : https://www.teguhhidayat.com/ accessed on March 25, 2021 ). 
The covid-19 virus that started in China and spread to all corners of the world and affects the business sector is certainly a consideration for a business person in carrying out or making investments. This is also not spared from the investment that occurred in Indonesia. (Adonu \& all, 2020) a study entitled Implications of Covid-19 on Human Resources Practices: A Case of the Ghanaian Formal Sector concluded that the impact of Covid-19 affects HR policies, procedures, and interventions across industries in Ghana. This is certainly not much different from investment or industrial activities that occur in Indonesia. As part of the anticipation carried out by the Indonesian government, Large-Scale Social Restrictions (PSBB) were carried out as well as the use of masks and washing hands using anti-septic. According to (Paryono, 2020) the impact of Covid-19 on investment in Indonesia, the Covid-19 virus spreads quickly and has spread to other regions in China and several countries, including Indonesia. This has led several countries abroad to implement policies to impose lockdowns to prevent the spread of the Coronavirus. In Indonesia itself, the Large-Scale Social Restriction (PSBB) policy was implemented. The COVID-19 outbreak has had a serious impact on almost all countries in the world, including Indonesia. The impact is not only in one area but in almost all existing activities. One aspect that is of concern amid the outbreak of the Coronavirus is an investment. The existence of various restrictions in a country certainly has an impact on economic activity.

Based on this explanation, this study was conducted to assess the effect of financial literacy, motivation, and risk on investment in Indonesia with the impact of Covid-19 as an intervening variable. 


\section{THEORETICAL REVIEW}

\section{The Effect of Financial Literacy on Investment in Indonesia with the Impact of Covid-19 as an Intervening Variable}

Financial literacy is defined as a combination of awareness, knowledge, skills, attitudes, and behaviors needed to make sound financial decisions that ultimately achieve individual financial well-being. In this variable, four aspects are used as benchmarks for someone to have financial literacy, namely basic financial concepts, saving and borrowing, insurance, and investment. Basic financial concept, the assessment carried out includes several things, such as knowledge about interest rates, inflation, and currency exchange rates. Saving and borrowing, the assessment carried out includes knowledge about savings and loans, such as credit. Insurance, the assessment carried out includes knowledge of insurance, such as life, health, and motor vehicle insurance products. Investment, the assessment carried out includes knowledge of market interest rates, stocks, bonds, and investment risks. ${ }^{9}$

In living life, every individual wants a more prosperous life, by managing his expenses and income in such

\footnotetext{
${ }^{9}$ S. Ariani, Pengaruh Literasi Keuangan, Locus Of Control dan Etnis Terhadap Pengambilan Keputusan Investasi. bttp://eprints.perbanas.ac.id/, , accessed on 24 May 2021
} 
a way as to produce the desired wealth. To be able to do all of that requires learning about the more specific financial activities that will be encountered such as recording and budgeting, banking and credit use, savings and loans, tax payments, investments, and retirement plans. In dealing with these problems, knowledge is needed. Financial literacy is an important factor in making financial decisions ${ }^{10}$. Today, Intellectual Capital (IC) and financial literacy, create knowledge and information and as a result, generate a wealth of knowledge-based economy capable of playing an important role in creating added value and gross domestic production. This significance can be caused by factors including the revolution in information technology, the increasing importance of science and a science-based economy as well as the influence of innovation and creativity as determinants of competition $^{11}$. According to Margaretha 2015 in Rizky Anugerah 2018, stated the financial knowledge possessed can determine financial products that can optimize financial decisions. Knowledge of finance is very important for individuals so that they are not wrong in making financial decisions later. If they lack financial knowledge, it will result in losses for the individual, either as a result of inflation or a

${ }^{10}$ Ariani, S. Pengaruh Literasi Keuangan, Locus Of Control dan Etnis Terhadap Pengambilan Keputusan Investasi. bttp://eprints.perbanas.ac.id/, 3. accessed on 24 May 2021

11 Abadi, HE, \& all, a. The effect of human s resources financial literacy and risk attitude on investors. International Journal of Human Capital in Urban Management, doi:: 0.22034/IJHCUM.2021.02.08 ( February 8, 2021 edition ). h. 193-208 


\section{Jufriadi}

decline in economic conditions at home and abroad. According to Lusardi, financial literacy is financial knowledge and the ability to apply it (knowledge and ability). Meanwhile, according to Moch. Zakki Zahrian Financial literacy can be interpreted as knowledge to manage finances. The higher the level of financial literacy that a person has will produce wise financial behavior and effective financial management. Based on this understanding, it can be defined that financial literacy will affect investment activities. However, even so, the impact of the Covid-19 impact will determine the direction of economic actors' decisions in investing even if they have financial literacy. According to Delali Adonu, et al in a study entitled Implications of covid-19 on Human Resource Practices: A case of The Ghanaian Formal Sector, world leaders in responding to the virus outbreak have set travel restrictions, announced stay-at-home orders, shut down, lockdown, closing facilities, and controlling workplace hazards. The COVID-19 outbreak has resulted in the suspension and realignment of many economic and human resource activities, worldwide including recreation, manufacturing, and education. This shows that the impact of COVID-19 has greatly affected all sectors throughout the world, including the investment sector in Indonesia. Based on the results of these studies, it can be concluded that financial literacy is very important for investment, but financial understanding and knowledge cannot be separated from the impact of COVID-19 in investing in Indonesia. Therefore, the investment process in Indonesia during the COVID-19 pandemic is still sluggish 
due to the sentiment and vigilance of economic actors against the impact of COVID-19.

\section{RESEARCH METHODS}

This research was conducted using descriptive research methods. Descriptive research is conducted by basing the relationship between variables based on references and the results of similar previous studies. The research variables used in this study include the dependent variable, namely investment, and the independent variable, namely financial literacy, motivation, investment risk, and the impact of Covid-19.

\section{RESULTS AND DISCUSSION}

The Effect of Motivation on Investment in Indonesia with the Impact of Covid-19 as an Intervening Variable

The purpose of investors to invest their capital is to obtain maximum profit (return) with a certain risk. With the capital market, investors can diversify their investments by forming portfolios following the expected returns and risks they are willing to bear. Basically, an efficient investment is an investment that provides the maximum level of profit with a certain risk ${ }^{12}$

12 Susanti, Motivasi Masyarakat Dalam Berinvestasi di Reksadana. https://www.semanticscholar.org/paper/,194. Taken back from https://www.semanticscholar.org/paper/MOTIVASI-MASYARAKAT- 


\section{Jufriadi}

Several factors encourage economic actors to invest:

1. The interest rate determines the types of investments that will provide benefits to the owners of capital (investors) in which investors will only invest their capital if the rate of return on capital invested ( return on investment) is in the form of a percentage of net profit (not deducted by the interest rate charged). paid) received is greater than the interest rate. An investor has two choices in using their capital, namely by lending or paying interest on the money (deposits), and using it for investment.

2. The predicted level of investment returns regarding future profits will provide investors with an idea of the type of business that is prospective and can be carried out in the future and the amount of investment that must be made to meet the additional capital goods required.

3. The level of national income and its changes. With the increase in national income, the level of people's income will increase, people's purchasing power will also increase, total aggregate demand will increase which in turn will encourage the growth of other investments (induced investment).

DALAM-BERINVESTASI-DI-REKSADANA- accessed on April 15, 2021 
4. The profits obtained by the company will encourage investors to provide a portion of the profits earned for new investments.

5. The political situation of a country will be a separate consideration for investors, especially foreign investors, to invest their capital. Given that investment is a relatively long period to recover the invested capital and gain profits, investors will highly expect long-term political stability.

6. Technological progress, with the findings of new technology (innovation), there will be more renewal activities that will be carried out by investors, so that the level of investors will be achieved.

7. The facilities provided by the government, the availability of various initial facilities and infrastructure, such as roads, electricity, and communication systems will encourage investors to invest in an area.

Meanwhile, according to Ferdiani, five factors motivate economic actors to invest, namely:

1. Anticipate the unexpected

Accidents, illness, or layoffs are something that is not expected. However, you cannot experience it in the future will come. Of course, no one knows about calamity. However, if this bad thing happens to you at a certain time, make sure you 


\section{Jufriadi}

have sufficient funds in anticipation. In times of calamity and unexpected events, it usually costs a lot of money.

At least you should be able to survive on the money you have while getting up and looking for new opportunities. Having an emergency fund and investing in anticipation of the future is very important. Collect money from salaries, consumptive snacks, and spending on less important necessities for emergency funds, insurance, and investing.

\section{The Wheel of Life Always Turns}

Maybe this time you can live comfortably, for example, have enough salary, a healthy body, higher job positions, and can buy anything else. However, of course, no one knows what will happen to you in the future. It could be that you were fired and it could be that you don't have that much salary in the future so considering the investment is quite important. If the wheel of your life is below right now, don't give up trying to always try. However, there are times when life doesn't go the way you expected.

It could be someday from the position of life at the top and then turning down. Ask yourself, are you ready to live life when your income is reduced and you can't make ends meet? So it is important to build a habit of saving and investing.

Start small first. Do your financial budgeting every month after receiving your salary and give a special portion for saving and investing. Do not set aside money to save at 
the end of the month, it could be that your money runs out first and fails to save.

\section{Preparation for Old Needs}

When you are young you may still be able to work strong. However, when you enter old age, your health may not be what it is today. From now on, you can target what kind of condition you want to retire in. Of course, it would be better to live a prosperous retirement without depending on anyone. Prepare for retirement from now on. Start doing this for long-term goals. It will be more comfortable if you have enough funds to live life in retirement. You can consider investments that suit your risk profile. The most important thing is to start being disciplined in providing money to invest in this and want to continue to learn the right knowledge.

\section{Grow Money Through Investment}

You've worked hard and saved, your money will be a pity if you just save it without intending to invest. The price of your money will be eroded by inflation every year. It's different if you save money on the right investment instruments. Even if you understand the right science, you can get a return that is not small and exceeds the value of inflation per year. Various prominent investors are successful because of this, for example, Lo Kheng Hong. You can learn the types of investment instruments, understand the science, and the risks. 


\section{Jufriadi}

Of course, doing this does not immediately make you rich. There is the knowledge that must be learned really and takes time. So be careful not to believe easily when offered a fraudulent investment mode with large and short returns. Doing this is not all about money.

In addition to investing through the money you have, it will be more important to do it for yourself. Learn about many things and develop the skills you have. Investing in yourself will be worth it, especially if you are young because you still have a long way to go and have the potential to become more successful.

\section{Plan goals to be achieved}

Saving and investing will be more excited when you have a certain target. In addition, with a target, it will be easier to achieve because you can measure how much you have to save per month. Determine your goals for saving, for example, to buy a vehicle, down payment on a house, collect business capital, perform the pilgrimage, or just travel. You have to believe in the goals you want to achieve. In addition to being confident, it is also important to make realistic targets. Measurable planning will be easier to achieve. You also find it easier to set aside money regularly to achieve planned dreams. That way you can open an account and choose the right investment according to your needs. You can also entrust funds to invest in P2P lending, Modal Rakyat. As a fund manager of choice, you can invest with us. It's never 
too late to start and remember some of the motivations you can use to get started with investing.

Besides that, there are forms of incentives provided by the government such as relief in taxation (tax holiday), which is a relief in the tax burden given to a company that wants to invest its capital ${ }^{13}$. Of course, based on these driving factors (investment motivation) it will increase the investment activity of economic actors, but the impact of Covid-19 will discourage economic actors from investing.

\section{The Effect of Risk on Investment in Indonesia with the Impact of Covid-19 as an Intervening Variable}

According to the Big Indonesian Dictionary (KBBI), the risk is an unpleasant (harmful, harmful) result of an action or action. Investment is not free from risk, and investment risk is directly proportional to the potential return, otherwise known as "high risk, high return." That is, if you want a large potential return or investment return, you must be prepared to take a high risk. Every investment decision always involves two things, namely risk and return. Risk has a positive and linear relationship with the expected return of an investment, so the greater the expected return, the greater the risk that must be borne by an investor. In making investment decisions, especially on stock securities, the returns obtained come from two sources, namely dividends and capital gains,

13 S. Budiharsono, Faktor-Faktor Yang Mempengarubi Investasi. p. 59. 


\section{Jufriadi}

while the risk of stock investment is reflected in the variability of income (stock returns) obtained. Investment risk is the possibility that an investment's cash flow will yield lower returns after investing in the latest investment instrument.

Jorion defines risk as the volatility of an expected return that is not, in general, the value of the asset or liability of interest. Gup, suggests that risk is a deviation from the expected return, while according to Jones in Ahmad Maftuhin, the risk is the possibility that the actual return on an investment will be different from the expected return. Brigham and Gapennski, argue that risk is the possibility that the profit received is less than the expected return.

In portfolio theory, the risk is expressed as the probability that the profit will deviate from the expected one. In portfolio theory, the risk is expressed as the probability that the return will deviate from the expected one. Therefore, risk has two dimensions, namely deviating greater or less than the expected return. Therefore, risk has two dimensions, namely deviating greater or less than the expected return. This measure is expressed in standard deviation) which is a measure for total risk.

According to Tandelilin in Ahmad Maftuhin, the total risk of various profit assets comes from:

1. Interest Rate Risk. The risk comes from the variability of returns due to changes in interest rates. Changes in interest rates hurt the price of interest rates. 
The Effect of Financial Literature, Motivation, And Risk on Investment....

2. Market Risk. The risk that comes from the variability of returns due to fluctuations in the overall market so that it affects all securities.

3. Inflation Risk. A factor that affects all securities is purchasing power risk. If interest rates rise, inflation will also increase, because lenders need an additional inflation premium to compensate for purchasing power losses.

4. Business Risks. The risk involved in doing business in a particular industry.

5. Financial Risk. Risks arising from the use of financial leverage by the company.

6. Liquidity Risk. The risks are associated with certain secondary markets in which securities are traded. An investment if it can be bought and sold quickly without significant price changes, then the investment is said to be liquid and vice versa.

7. Country Risk. This risk concerns the politics of a country so that it leads to political risk. In contrast to traditional analysis, modern investment analysis divides total risk into two parts, namely systematic risk, and unsystematic risk ${ }^{14}$. Unsystematic risk is the risk caused by factors in particularity and can be

14 Abdullah Umar, Berani Mengambil Resiko. bttps:/ / binus.ac.id/entrepreneur/2018/11/26/ berani-mengambil-resiko-abdullabumar-st-mm/. Accessed on 26 March 2021 


\section{Jufriadi}

eliminated by eliminating diversification. While systematic risk is the risk caused by macro factors that affect all securities so that it cannot be eliminated by diversification, because some risks can be eliminated by diversification, namely unsystematic risk ( unique risk ), then the risk measure of a portfolio is no longer standard deviation (total risk), but only systematic risk, that is, the risk that cannot be eliminated by diversification. These risks are something that has been able to be predicted by economic actors so that they will try to keep investing by minimizing risk. However, this is different from the impact of COVID-19, which has such a large impact because it affects all sectors around the world. This is in line with research conducted by Delali Adonu, et al in a study entitled Implications of Covid-19 on Human Resources Practices: A Case of the Ghanaian Formal Sector. Therefore, it can be concluded that risk does not affect investment in general, but in terms of the impact of Covid-19, it is considered by investors by looking at the impact throughout the world in all sectors.

Based on references and previous research results used as references, it can be stated that financial literacy, motivation, and risk will be greatly influenced by the impact of COVID-19 in making decisions to invest in Indonesia. All references used and the results of previous research including research conducted by $\mathrm{H}$. Eslami Mofid Abadi, et al with the 
title The Effect of Human Resources Financial Literacy and Risk. Attitude on Investor Motivation in 2020 show that financial literacy, motivation, and risk affect investment, but the presence of and the impact of Covid-19 has caused economic actors around the world to consider investing, including in Indonesia. This is under the results of research conducted by Delali Adonu, et al in a study entitled Implications of Covid-19 on Human Resources Practices: A Case of the Ghaniaan Formal Sector in 2021.

\section{CONCLUSIONS}

Based on the results of the study, it can be concluded that the impact of Covid-19 is a determining factor in investing in Indonesia because it can influence financial literacy, motivation, and investment risk that is understood by investors in investing, especially in Indonesia. Therefore, the author suggests to the government and all citizens to work together to overcome Covid-19 so that it can be destroyed, at least reduced so that it can return world investment, especially in Indonesia.

\section{REFERENCES}

Abadi, H. E., \& all, a. (2021, Februari 8 Februari). The effect of human resources financial literacy and risk attitude on investor. International Journal of Human Capital in 
Jufriadi

Urban Management, 193-208. doi:: 10.22034/IJHCUM.2021.02.08

Abdullah Umar, S. M. (2018). Berani Mengambil Resiko. https:/ / binus.ac.id/entrepreneur/2018/11/26/beranimengambil-resiko-abdullah-umar-st-mm/.

Adonu, D., \& all, a. (2020, November 19 November). Implications of COVID-19 on Human Resource Practices: A Case of the Ghanaian Formal Sector. Journal of Human Resource Management, Vol. 8, No. 4, 209-214. doi:10.11648/j.jhrm.201200804.11

Anugerah, R. (2018). Pengaruh Literasi Keuangan dan Sikap Keuangan. http:/ / repositori.uin-alauddin.ac.id/.

Ariani, S. (2015). Pengaruh Literasi Keuangan, Locus Of Control dan Etnis Terhadap Pengambilan Keputusan Investasi. bttp:/ / eprints.perbanas.ac.id/.

Budiharsono, S. (2019). Faktor-Faktor Yang Mempengaruhi Investasi.

Darmawan, A. (2019). Pengetahuan Investasi, Motivasi Investasi, Literasi Keuangan dan Lingkungan Keluarga Pengaruhnya Terhadap Investasi di Pasar Modal. bttps://www.researchgate.net/journal/JurnalIlmiah-Akuntansi-dan-Keuangan-2548-9453.

Ferdiani, K. R. (2020, Juli 13 Juli). Motivasi Melakukan Investasi. Taken back from https://www.modalrakyat.id/: https://www.modalrakyat.id/

Hidayat, T. (2014, Maret 25 Maret). bttps://mmw.tegubhidayat.com/. Taken back from https://www.teguhhidayat.com/: https://www.teguhhidayat.com/ 
Kredit.com, S. (2021, Juni 12). https:// www.simulasikredit.com/. Taken back from https://www.simulasikredit.com/: https://www.simulasikredit.com/

Maftuhin, A. (t.thn.). Makalah Investasi. Taken back from https://www.academia.edu/12245879/Makalah_Inv estasi:

https://www.academia.edu/12245879/Makalah_Inv estasi

Paryono, E. (2020, Mei 13 Mei). Dampak Covid-19 terbadap Investasi di Indonesia. Taken back from https://www.kompasiana.com:

https://www.kompasiana.com/ediparyono/5ebbb3

b7097f36638a07a1b2/dampak-covid-19-teradapinvestasi-di-indonesia

Sugiantini. (2018, Juni 15 Juni). BERB $A G A I M A N F A A T$ TEKNOLOGI BAGI KEHIDUPAN MANUSLA. Taken back from https:/ / sugiantini.blog.institutpendidikan.ac.id:

Berbagai Manfaat Teknologi Bagi Kehidupan Manusia

Susanti, I. (2011). Motivasi Masyarakat Dalam Berinvestasi di Reksadana. https:// www.semanticscholar.org/paper/, 194. Taken back from https://www.semanticscholar.org/paper/MOTIVA SI-MASYARAKAT-DALAM-BERINVESTASIDI-REKSADANA-

Susanti/8f7921519a4def0f9d0d4c79190094a6a1ff07e 3 